\title{
TOURIST SHIPS ON THE DANUBE AS AN OPPORTUNITY FOR EXPORT OF MEAT AND MEAT PRODUCTS ${ }^{1}$
}

\author{
Dragan Tešanovič², Nikola Vuksanović3 ${ }^{3}$ Bojana Kalenjuk4, Milijanko Portič́5
}

\begin{abstract}
Summary
Tourism development launches growth of other complementary industries. River tourism, as a special selective tourism form, experiences intensive development, with an importance for all the regions through which the Danube, as an integral part of the Rhine - MainDanube waterway, flows. During cruising, the largest consumption is achieved on the ship itself, where meat and meat products are an integral element of every meal and represent the most expensive component of the dish. The task of this paper is to analyse the consumption of meat and meat products on six tourist ships run by to "Grand Circle Corporation" in 2013, in order to point out the possibility of supplying them with meat and meat products from sources in the territory where the ships sail. The paper presents the current suppliers and manufacturers of meat and meat products in Republic of Serbia that could supply the company , Grand Circle Cruise Line“ and other tourist ships that cruise on the Danube. Also, the research indicates that the export of meat products from the Republic Serbia could have a significant effect on improving the agricultural conditions and food production through increased competition, assuming the Serbian manufacturers supply most of tourist ships and not only the six ships analysed in this paper. Research results, specifically, point out the possibility of increasing export of poultry and beef if the potential demand of each
\end{abstract}

1 This paper is a part of the projects III 46009 and III 46005, financed by the Ministry of Education, Science and Technological development of the Republic of Serbia, whom the authors want to express their gratitude.

2 Dragan Tešanović, Ph.D., Full Professor, University of Novi Sad, Faculty of Science, Department of Geography, Tourism and Hotel Management, 21000 Novi Sad, Republic of Serbia, Trg Dositeja Obradovića 3, Phone: +381 63541 436, E-mail: tesanovic.dragan@gmail.com

3 Nikola Vuksanović, M.Sc., Teaching Assistant, Higher education school for management and business communication, Department of Hospitality, 21205 Sremski Karlovci, Republic of Serbia, Mitropolita Stratimirovića Street 110, Phone: +381 631968 770; E-mail: vuksanovicnikola@yahoo.com

4 Bojana Kalenjuk, Ph.D., Assistant Professor, University of Novi Sad, Faculty of Science, Department of Geography, Tourism and Hotel Management, 21000 Novi Sad, Republic of Serbia, Trg Dositeja Obradovića Street 3, Phone: +381 6419902 35, E-mail: bojanakalenjuk@yahoo.com

5 Milijanko Portić, Ph.D., Associate Professor, University of Novi Sad, Faculty of Science, Department of Geography, Tourism and Hotel Management, 21000 Novi Sad, Republic of Serbia, Trg Dositeja Obradovića Street 3, Phone: +381 63814 47 39, E-mail: porticprof@yahoo.com

EP 2015 (62) 2 (527-542) 
of the eight companies with their 54 ships which operate tourist cruises on the Danube is taken into account. The data have been systematized, analysed and presented statistically in tables and graphs.

Key words: Danube tourist ships, meat, meat products, export.

JEL: L83, O13, Q13, Q11

\section{Introduction}

Thanks to the favourable climate, good natural characteristics of the land and available water resources Serbia has a great potential in the sector of agriculture and food production and thus has the possibility to conquer the market provided that they meet the international quality standards. In addition, tourism has become an important source of income due to, among other things, the Danube (Popović et al., 2012), where a large number of tourist ships sail. These ships could be a new segment on the market and possibility to export agricultural and food products.

The Danube is one of the most frequently visited tourist destinations in Serbia. River tourism has an increasing growth rate in Europe and an even more expansive rate is predicted for the future (Katić et al., 2011), making the Danube, as a traveling route, an important factor of economic development for Serbia (Vitez, Raičević, 2008).

The Danube has the longest flow through Serbia, and yet not a single business entity from Serbia supplies the ships' kitchen with foodstuffs (Tešanović et al., 2010a; Tešanović et al., 2010b; Tešanović et al., 2013), or other goods.

Tourism, agriculture and food industry are interconnected (Hrabovski-Tomić, 2010), and Meler and Cerović (2003) suggest that expenditures in food and drink in tourism account for one-third of the total tourist consumption of global tourism traffic. As a result of the tourists' consumption at a certain destination, tourism impacts the economy (Đenadić, 2010).

The topic of this paper is the consumption of meat and meat products on the tourist ships which pass through the Republic of Serbia because the meat is the basic and the most expensive component of every meal and most used after foods of plant origin (Kalenjuk et al., 2011; Tešanović et al., 2013). In this paper, the meat of warm-blooded animals (beef, veal, lamb and pigs), poultry meat and meat products will be discussed. Meat production in Serbia has a long tradition and some of the greatest successes of Serbian agriculture are linked specifically to the production of meat.

The task of this paper is to analyse the types and quantities of meat and meat products, which are consumed on the riverboats owned by "Grand Circle Cruise Line" which sail through the Republic of Serbia. The aim of the study is to determine which types of meat and meat products that are consumed on tourist ships of the company "Grand Circle Cruise Line" could be supplied by the producers in the Republic of Serbia. This should also indicate the possibility to export the same products that are consumed on tourist ships of the company "Grand Circle Cruise Line" to other companies that operate on the Danube, thus increasing the sales of meat in the Republic of Serbia. 


\section{Literature review}

\section{The potential of the Danube River}

At its lenght of $2,888 \mathrm{~km}$, Danube is the second largest European river. Originating in Germany, the Danube flows through 10 countries in total: Germany, Austria, Slovakia, Hungary, Croatia, Serbia, Bulgaria, Romania, Moldova and Ukraine, and flows into the Black Sea on the territory of Romania (Katić et al., 2011). It is a part of the Trans-European navigation system of Rhine-Main-Danube waterway and connects the Atlantic with the Mediterranean (Mihić et al., 2011), thus giving it the ability to transport cruise ships from all over the world (Katić et al., 2011). The development of tourism on the Danube River and of the Danube region itself represents one of the priority directions of the overall development of Vojvodina.

\section{Trends in nautical tourism}

In 2013, the worldwide cruise market was estimated at $\$ 36.2$ billion, up 4.8\% from 2012; cruise passengers carried worldwide in 2013 is predicted to come at 20.9 million, a 3.3\% increase over 2012; the top two cruise companies are Carnival Corporation and Royal Caribbean Cruises Ltd. Co. (they account for $71.7 \%$ of worldwide share of revenue); total worldwide cruise capacity at the end of 2013 was 438,595 passengers ( $3 \%$ increase over 2012) and 283 ships (Cruise Market Watch, 2012).

In the period of 2008 to 2013 , river cruises recorded $10 \%$ of annual increase in the number of passengers while the cruise industry as a whole experienced an average growth of about $7 \%$ per year. According to the company Cruise Travel Outlet, river cruise lines currently face a problem to keep up with the demand. Namely, the majority of the companies had already booked a year in advance all the available river cruising places for the 2014 cruising season (Market Watch, 2013).

The steady growth of nautical tourism is also evident in Serbia, despite the scarcity of more recent data: year 2002 saw 101 tourist ships in the entire country, with 12,185 passengers, while this number grew more than nine-fold, to 915 ships in 2007 with 117,078 passengers. In addition to the steady growth of ships and passengers, the percentage of foreign tourists among those passengers has also been increasing: starting from $3.9 \%$ in 2002 to $16.8 \%$ in 2007, with a pique in 2005 with $21.2 \%$ (Dragin et al., 2010; Dragin et al., 2014).

According to the research conducted by Dragin et al. $(2010 ; 2014)$ the cruises on the Danube have a positive impact on Vojvodina Province, primarily the riparian area of the Danube (only Novi Sad - the "Port of Vojvodina for cruisers"). It can be noted in the research that the number of tourists on the Corridor VII (in Vojvodina Region) is increasing every year. Danube river cruise market recorded annual increases, which means economic impact of cruise tourism. Further research is necessary for more specific economic impact. 


\section{Production and sale of meat in the world and in domestic markets}

Đorović and associates $(2009 ; 2010)$ point out that an increase in the production of meat is a characteristic of economic development. These authors have studied the meat production globally in the period from 1989 to 2008 using three cross-sections: 1989-1991, 1998-2000 and from 2006 to 2008. The average annual growth rate of meat production was $2.5 \%$ in the period of 2006-2008. Compared with the initial period analysed by the authors (1989-1991), the production of meat has increased by $59 \%$ and represents about 286 million tons of meat and meat products. Out of the 15 largest meat producing countries (U.S. 18\% of world meat production, Brazil 12.1\%, China $7.8 \%$ and in Europe: Russia 2.7\%, France 2.3\% and Germany 1.8\%) developed countries provide most of the world's production of beef and buffalo meat at $62 \%$, while developing countries have a higher share in world production of pork, poultry, mutton and goat meat.

Meat and meat products are essential in the diet of the people in developed countries (Saba, Di Natale, 1999; Grunert, 2006). Fernandez Gines and associates (2005) state that the meat industry is one of the most important food industries in the world with a continuous increase not only in consumer demand but also in the development of competition, which emphasizes the continuous research of new products.

In the global production of meat, pork is produced the most, with a share of about $41 \%$, followed by poultry, with a share of about $30 \%$. Beef and buffalo meat are in the third place at about $23 \%$, while sheep and goat meat are at around $5 \%$ of the share and are in the fourth place (Đorović et al., 2009, 2010). The participation of Serbia in the total world production of meat is extremely modest, at around $0.17 \%$. Wherein, the production of beef and poultry accounts for approximately $0.1 \%$, while the production of pork and mutton for about $0.2 \%$ (SORS, 2012).

Đorović and associates $(2009 ; 2010)$ stated that the meat production in Serbia during the period of their evaluation, from 1989 to 2008 , is characterized by permanent decrease and it is at the level of about 500,000 tons. With a negative growth rate of $-0.7 \%$, during the second cross-section period the production fell by $6.5 \%$ and even more in the third period, as much as $12.6 \%$. The only kind of meat which saw an increase was pork, with a symbolic increase of $0.9 \%$ (SORS, 2012). Serbia is the largest producer, consumer and exporter of all kinds of meat in the CEFTA countries.

Table 1 shows the production of fresh meat in the Republic of Serbia from 2009 to 2013. Comparing the annual consumption of tourist ships sailing on the Danube and passing through the Republic of Serbia to the annual production of meat in the Republic of Serbia, it can be noticed that those are significant quantities of meat which could result in increased production and export in meat industry. 
Table 1. Meat production in the Republic of Serbia

\begin{tabular}{|c|c|c|c|c|}
\hline \multicolumn{5}{|c|}{ Production of fresh meat and meat products in the Republic of Serbia } \\
\hline *thous. tons & Beef & Pork & Mutton & Poultry meat \\
\hline $\mathbf{2 0 0 9}$ & $100 *$ & 252 & 24 & 80 \\
\hline $\mathbf{2 0 1 0}$ & 96 & 269 & 23 & 84 \\
\hline $\mathbf{2 0 1 1}$ & 81 & 271 & 24 & 103 \\
\hline $\mathbf{2 0 1 2}$ & 82 & 252 & 22 & 94 \\
\hline $\mathbf{2 0 1 3}$ & 70 & 249 & 30 & 92 \\
\hline
\end{tabular}

Source: SORS, 2012-2014.

The production of beef, pork and lamb meat in 2010, despite the small number of cattle, totalled 388,000 tons (Petrović et al., 2011) which can unconditionally provide the needs of all tourist ships that pass through Serbia, since the production of beef and pork is less emphasized compared to poultry and meat products.

\section{The status of export and import agricultural and food products in the Republic of Serbia}

In the period from 2000 to 2010, the overall export of agricultural and food products from the Republic of Serbia was at the average annual level of 1.14 billion USD, and an analysis indicates that meat and meat products are in the second place according to the Institute for Statistics of the Republic of Serbia (SORS, 2012). In the structure of the total value of exports and imports of fresh meat, exports share is about $52 \%$, and imports is about $31 \%$, while processed meat export has a share of about 48\%, and import of about 69\% (Đorović et al., 2010).

Đorović and associates (2010) reported that the largest export of fresh, chilled and frozen meat is directed to Macedonia, Italy, Greece, the United Arab Emirates, Bosnia and Herzegovina, Montenegro, Congo, China and Vietnam. At the same time, the import of these products is usually from Austria, Germany, Spain, Netherlands, Belgium, Italy, Hungary, Greece, France and Slovenia.

\section{Trends and consumer lifestyles in relation to the consumption of meat}

Previous studies (Saba, Di Natale, 1999; Fernandez-Gines et al., 2005; Grunert, 2006) indicate the need of market research that is focused on consumers, and the analysis of external factors, such as their needs, attitudes, habits and lifestyles. The industry for agrofood products, in order to be competitive on the market, should pay attention to these external factors which influence the selection of products (Saba, Di Natale, 1999; Grunert, 2006). An opportunity for fragmentation and product differentiation of the meat market opens for the producers based on these external factors. The results of the market analysis indicate the frequent occurrence of interactions between consumer, attitudes and lifestyles in relation to the selection of products (Saba, Di Natale, 1999; Grunert, 2006), which later determines the way the manufacturers produce agricultural and food products. Same logic applies to the field of tourism: Permanent monitoring of the needs and demands of consumers or tourists is not only important for the agro-food industry, but also for tourism, in particular for the hospitality and the selection of the most appropriate parts of the meat for preparing and serving. 


\section{Research methods}

Six ships which sail on the Rhine-Main-Danube Canal, each with a capacity of 140 passengers, constitute the sample used for the purposes of this research. The sample represents $10.4 \%$ of the total tourist turnover of cruisers docked in Novi Sad during 2007, which were 54 ships. In 2007, tour operators were mainly from the USA (Massachusetts - Grand Circle Travel and Grand Circle Corporation, California Viking River Cruises), Germany (Peter Deilmann, Phoenix Reisen Gmbh and Nicko Tours), Denmark (Quality Tours) and France (Croisieurope). Usual capacity of the ships ranged between 48 and 180 tourists.

The internal documentation of company "Grand Circle Corporation" from 2013 was used for the purpose of this research, showing the structure and amount of consumption of fresh meat and meat products by type for each of the 6 ships individually. The method of descriptive statistics was applied for the consumption analysis. The results are presented in tables and graphs. During the research of literature the methods of synthesis and analysis, which are combined according to specific research in this paper, were used.

\section{The annual consumption of meat and meat products in the company "Grand Circle Cruise Line"}

Consumption of agricultural and food products is a continuous biological and social process that has a fundamental importance. Considering that the problem of food in the world is always present the proper nutrition means eating foods of plant and animal origin, which contain essential nutrients. The company offers its passenger's properly balanced meals for whose preparation they procure fresh food at certain destinations during navigation (Vlahović, Štrbac 2006; Vlahović, Puškarić, 2006).

The Company does not purchase foodstuffs in Serbia, even though the longest flow of the Danube is in the Republic of Serbia, and therefore the retention of ships is the longest. Purchasing for the leg of the voyage through Serbia is done in Budapest in Hungary. The following table lists the companies that supply ships with products and where they operate.

Table 2. - Supplying Companies

\begin{tabular}{|l|l|l|}
\hline \multicolumn{1}{|c|}{ Company } & \multicolumn{1}{c|}{ Type of products } & \multicolumn{1}{c|}{ Country (Itinerary) } \\
\hline $\begin{array}{l}\text { HMS Group } \\
\text { www.hmsgroup.com }\end{array}$ & $\begin{array}{l}\text { Fresh dairy, precooked and } \\
\text { frozen products }\end{array}$ & $\begin{array}{l}\text { Netherlands - Germany - } \\
\text { Austria - Hungary }\end{array}$ \\
\hline $\begin{array}{l}\text { NORDIS } \\
\text { www.nordis.nl }\end{array}$ & fresh fruit and vegetables & Netherlands - Germany \\
\hline $\begin{array}{l}\text { DRIESSEN } \\
\text { www.driessenfood.nl }\end{array}$ & fresh and frozen meat and fish & Netherlands - Germany \\
\hline $\begin{array}{l}\text { Heinz J. Penz } \\
\text { www.penz.at }\end{array}$ & fresh fruit and vegetables & $\begin{array}{l}\text { Germany (south) - Austria - } \\
\text { Hungary }\end{array}$ \\
\hline
\end{tabular}

Source: Internal documentation of Grand Circle Corporation, 2013. 
It can be concluded from the Table 2, that the company supplies their ships with meat and meat products from two companies: HMS Group and DRIESSEN based in the Netherlands, and they transport between Germany, Austria and Hungary.

The following data about the different kinds of meat and meat products used in preparing meals refers to the total annual consumption on the six ships that were analysed for this paper.

Beef, veal and lamb consumption - Based on the insight of the internal documentation, it can be concluded that ships kitchens use 10 parts of the beef from which, according to Regulations on the meat quality of livestock for slaughter, poultry and game (Official Gazette, Republic of Serbia, no. 34/74, 26/75, 13/78 - other Regulations, 1/81 - other Regulation and 2/85 - other Regulations), eight parts are of the first category, one part of the second category (Veal hind shank) and one part of the third category (Veal bones cut). Table 2 presents all of the different kinds of cattle meat which are used. The Beef rump cap (Tafelspitz) stands out with the biggest consumption of $2,325.39 \mathrm{~kg}$.

Table 3. - Beef, veal and lamb consumption

\begin{tabular}{|c|c|c|c|c|c|c|c|c|c|}
\hline \multirow[b]{2}{*}{$\frac{\grave{d}}{\grave{E}}$} & \multirow[b]{2}{*}{$\begin{array}{c}\text { Name of foods that are } \\
\text { purchased }\end{array}$} & \multirow[b]{2}{*}{ 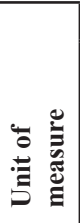 } & \multicolumn{7}{|c|}{ Annual consumption by ships } \\
\hline & & & 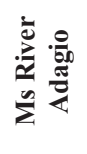 & $\sum_{\infty}^{\infty}$ & 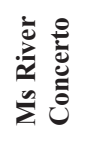 & 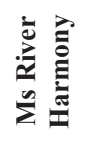 & 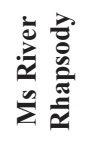 & 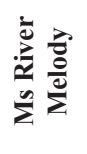 & Total \\
\hline \multicolumn{10}{|c|}{ Beef } \\
\hline 1 & Beef Entrecote boneless & $\mathrm{kg}$ & 76.1 & 48.64 & 65.78 & 107.89 & 171.06 & 119.83 & 589.3 \\
\hline 2 & $\begin{array}{l}\text { Beef legs boneless } \\
\text { (goulash meat) }\end{array}$ & $\mathrm{kg}$ & 346.4 & 555.06 & 222.68 & 227.99 & 232.31 & 112.25 & $1,696.69$ \\
\hline 3 & $\begin{array}{l}\text { Beef roast beef (Sirloin) } \\
\text { Maredo }\end{array}$ & $\mathrm{kg}$ & 19.39 & 44.82 & 55.68 & 11.82 & 56.91 & 62 & 250.62 \\
\hline 4 & $\begin{array}{l}\text { Beef roast beef (Sirloin) } \\
\text { Argentinian }\end{array}$ & $\mathrm{kg}$ & 470.47 & 383.83 & 282.93 & 126.58 & 378.63 & 454.08 & $2,096.52$ \\
\hline 5 & $\begin{array}{l}\text { Beef rump cap } \\
\text { (Tafelspitz) }\end{array}$ & $\mathrm{kg}$ & 387.46 & 629.82 & 289.29 & 288.51 & 385.16 & 345.15 & $2,325.39$ \\
\hline 6 & $\begin{array}{l}\text { Beef eye of round } \\
\text { semerrolle boneless }\end{array}$ & $\mathrm{kg}$ & 191.49 & 200.56 & 180.57 & 199.5 & 301.39 & 225.96 & $1,299.47$ \\
\hline 7 & Beef tenderloin & $\mathrm{kg}$ & 349.61 & 384.36 & 342.08 & 257.41 & 272.28 & 323.04 & $1,928.78$ \\
\hline 8 & $\begin{array}{l}\text { Beef topside boneless } \\
\text { Argentina }\end{array}$ & $\mathrm{kg}$ & 78.56 & 34.81 & 87.36 & 29.55 & 50.84 & 51.96 & 333.08 \\
\hline \multicolumn{10}{|c|}{ Lamb } \\
\hline 9 & Lamb legs boneless & $\mathrm{kg}$ & 157.89 & 129.43 & 107.05 & 129.36 & 265.77 & 143.42 & 932.92 \\
\hline 10 & Lamb rack & $\mathrm{kg}$ & 411.08 & 431.29 & 282.88 & 268.84 & 310.18 & 338.99 & $2,043.26$ \\
\hline \multicolumn{10}{|c|}{ Veal } \\
\hline 11 & Veal bones cut & $\mathrm{kg}$ & 25 & 320.7 & 280.34 & 161.11 & 260.96 & 90.14 & $1,138.25$ \\
\hline 12 & Veal hinds hank & $\mathrm{kg}$ & 37.53 & 45.01 & 41.52 & 117.04 & 101.65 & 97.58 & 440.33 \\
\hline \multicolumn{9}{|c|}{ Total } & $15,074.61$ \\
\hline
\end{tabular}

Source: Internal documentation of Grand Circle Corporation, 2013. 
Pork consumption - Ten parts of the pork meat are used for preparing the meals. Share of the parts of the meat by category (Regulations on quality of slaughtered pork and categorization of pork meat; Official Gazette Republic of Serbia, no. 2/85, 12/85 and 24/86) are: three from the first category (Pork tenderloin w/head, Ham pork salted and, Pork loin w/out chain or Pork cutlets), two from the second category (Pork smoked rolled roast and Pork neck boneless), three from the third category (Pork meat goulash, hind shank and spareribs) and one from special category - pork in one piece (Pork suckling pig). Pork loin w/out chain stands out with the biggest consumption of 2,388.1 $\mathrm{kg}$, followed by Pork neck boneless with 2,024.91 kg and Pork suckling pig with $1,225.74 \mathrm{~kg}$. Other parts are also in use, like: Pork smoked rolled roast, Pork cutlets, Pork goulash, Pork hind shank, Pork tenderloin w/head and chain and Ham pork salted, as shown in table 4.

Table 4. - Pork consumption

\begin{tabular}{|c|c|c|c|c|c|c|c|c|c|}
\hline \multirow[b]{2}{*}{$\frac{\grave{d}}{\grave{\Xi}}$} & \multirow[b]{2}{*}{$\begin{array}{c}\text { Name of foods that are } \\
\text { purchased }\end{array}$} & \multirow{2}{*}{ 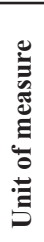 } & \multicolumn{7}{|c|}{ Annual consumption by ships } \\
\hline & & & 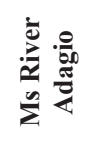 & 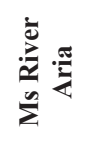 & 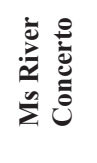 & 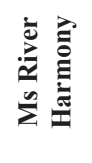 & 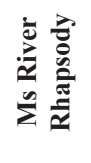 & 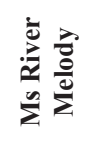 & Total \\
\hline \multicolumn{10}{|c|}{ Pork } \\
\hline 1 & Pork smoked rolled roast & $\mathrm{kg}$ & 130.42 & 72.24 & 103.24 & 183.21 & 207.66 & 150.78 & 847.55 \\
\hline 2 & Pork loin cutlets & $\mathrm{kg}$ & 11.2 & 174.3 & 219.28 & 289.97 & 146.32 & 71.66 & 912.73 \\
\hline 3 & Pork meat goulash & $\mathrm{kg}$ & 210 & 270.74 & 30 & 145 & 40 & 87.5 & 783.24 \\
\hline 4 & Pork hinds hank & $\mathrm{kg}$ & 55.02 & 42.17 & 36.81 & 121.36 & 109.37 & 124.47 & 489.2 \\
\hline 5 & Pork loin w/out chain & $\mathrm{kg}$ & 325.07 & 430.19 & 404.93 & 356.33 & 415.7 & 455.88 & 2388.1 \\
\hline 6 & Pork neck boneless & $\mathrm{kg}$ & 445.76 & 252.26 & 484.22 & 248.04 & 383.5 & 211.13 & $2,024.91$ \\
\hline 7 & Pork spareribs & $\mathrm{kg}$ & 180 & 190.02 & 130 & 200 & 221.17 & 241.01 & $1,162.2$ \\
\hline 8 & Pork suckling - whole pig & $\mathrm{kg}$ & 134.73 & 187.37 & 168.5 & 258.51 & 247.9 & 228.73 & $1,225.74$ \\
\hline 9 & $\begin{array}{l}\text { Pork tenderloin } \mathrm{w} / \text { head } \\
\text { \& chain }\end{array}$ & $\mathrm{kg}$ & 87.39 & 110.8 & 116.1 & 104.07 & 125.76 & 109.95 & 654.07 \\
\hline 10 & Ham pork salted & $\mathrm{kg}$ & 213.8 & 192.3 & 130.61 & 119.28 & 70.6 & 53.98 & 780.57 \\
\hline \multicolumn{9}{|c|}{ Total } & $11,268.31$ \\
\hline
\end{tabular}

Source: Internal documentation of Grand Circle Corporation, 2013.

Poultry consumption - The analysis of data on the consumption of poultry meat, shown in Table 4, shows that Chicken breast fillet is the most consumed part $-6,830.44 \mathrm{~kg}$, followed by Turkey breast boneless with $1,673.28 \mathrm{~kg}$. There is only one part of game that is used - Duck legs with 4,834.3 kg. Other parts of meat are also used, such as: Chicken legs boneless, Chicken legs bone-in, Chicken liver, Chicken wings, Turkey legs (rollbraten dark meat), Turkey whole without insides with skin, and also products from chicken Chicken Cordon Blue and Chicken nuggets. 
Table 5. - Poultry consumption

\begin{tabular}{|c|c|c|c|c|c|c|c|c|c|}
\hline \multirow[b]{2}{*}{$\frac{\dot{\Xi}}{\grave{E}}$} & \multirow[b]{2}{*}{$\begin{array}{c}\text { Name of foods that are } \\
\text { purchased }\end{array}$} & \multirow[b]{2}{*}{ 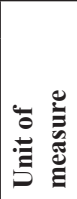 } & \multicolumn{7}{|c|}{ Annual consumption by ships } \\
\hline & & & 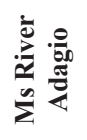 & 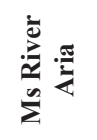 & 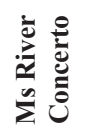 & 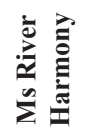 & 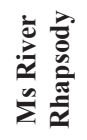 & 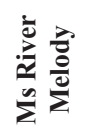 & Total \\
\hline \multicolumn{10}{|c|}{ Poultry } \\
\hline 1 & Chicken breast fillet & $\mathrm{kg}$ & 918.84 & $1,034.2$ & 895.64 & 1235.1 & $1,580.0$ & $1,166.7$ & $6,830.44$ \\
\hline 2 & Chicken legs boneless" & $\mathrm{kg}$ & 122.64 & 54.4 & 217.64 & 137.98 & 10.2 & 20.14 & 563 \\
\hline 3 & Chicken legs bone-in & $\mathrm{kg}$ & 590.64 & 629.42 & 603.43 & 552.14 & 831.88 & 365.76 & $3,573.27$ \\
\hline 4 & Chicken liver & $\mathrm{kg}$ & 80 & 73.34 & 109.54 & 109.06 & 71.18 & 111.6 & 554.72 \\
\hline 5 & Chicken whole (up to $1 \mathrm{~kg}$ ) & $\mathrm{kg}$ & 600.54 & 560.26 & 782.7 & 680.22 & 782.78 & 940 & 4346.5 \\
\hline 6 & Chicken wings & $\mathrm{kg}$ & 237.34 & 195.46 & 70 & 245.18 & 210.96 & 186.54 & $1,145.48$ \\
\hline 7 & Duck legs & $\mathrm{kg}$ & 734 & 985 & 790 & 671 & 914.3 & 740 & 4834.3 \\
\hline 8 & Turkey breast boneless & $\mathrm{kg}$ & 293.9 & 351.74 & 275.02 & 261.89 & 234.31 & 256.42 & $1,673.28$ \\
\hline 9 & $\begin{array}{l}\text { Turkey legs (rollbraten-dark } \\
\text { meat) }\end{array}$ & $\mathrm{kg}$ & 195 & 190.22 & 132.27 & 151.54 & 34.3 & 142.75 & 846.08 \\
\hline 10 & $\begin{array}{l}\text { Turkey whole w/out insides } \\
\text { w/skin }\end{array}$ & $\mathrm{kg}$ & 284.7 & 196.71 & 227.53 & 212.04 & 314 & 294.67 & $1,529.65$ \\
\hline \multicolumn{10}{|c|}{ Precooked products of chicken meat } \\
\hline 11 & Chicken Cordon Blue & $\mathrm{kg}$ & 200 & 132 & 144 & 139 & 107 & 225 & 947 \\
\hline 12 & Chicken nuggets & $\mathrm{kg}$ & 105 & 62 & 34 & 153 & 78 & 99 & 531 \\
\hline \multicolumn{9}{|c|}{ Total } & $27,374.72$ \\
\hline
\end{tabular}

Source: Internal documentation of Grand Circle Corporation, 2013.

Meat products consumption - Different kinds of meat products which are used on ships are shown in table 6. Ships purchase and use 19 types of meat products, of which Bacon smoked whole for breakfast stands out with the consumption of $8645.73 \mathrm{~kg}$, followed by Minced mixed meat with 3,688 kg and Ham cooked breakfast with 3,410.51 kg. Other meat products that are also consumed are: Cold cuts salami white, Sausage smoked Rockworst, Sausage Bavarian white, Cold cuts turkey assorted, Cold cuts assorted, Sausage Vienna, Sausage Breakfast (20-25gr) and Beef Hamburger.

Table 6. - Meat products consumption

\begin{tabular}{|c|c|c|c|c|c|c|c|c|c|}
\hline \multirow[b]{2}{*}{$\frac{\dot{0}}{\text { ह }}$} & \multirow[b]{2}{*}{$\begin{array}{c}\text { Name of } \\
\text { foods that are } \\
\text { purchased }\end{array}$} & \multirow[b]{2}{*}{ 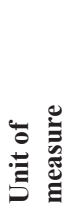 } & \multicolumn{7}{|c|}{ Annual consumption by ships } \\
\hline & & & 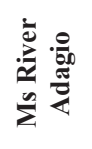 & $\sum_{\substack{\infty \\
\Sigma}}^{\frac{\pi}{2}}$ & 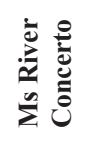 & 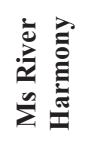 & 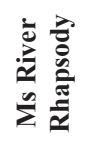 & 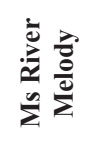 & Total \\
\hline \multicolumn{10}{|c|}{ Bacon } \\
\hline 1 & $\begin{array}{l}\text { Bacon smoked } \\
\text { whole for breakfast }\end{array}$ & $\mathrm{kg}$ & $1,591.2$ & $1,980.8$ & $1,431.1$ & $1,089.4$ & $1,234.5$ & $1,318.76$ & $8,645.73$ \\
\hline \multicolumn{10}{|c|}{ Sausages - Fermented dry sausage } \\
\hline 2 & $\begin{array}{l}\text { Cold cuts salami } \\
\text { white }\end{array}$ & $\mathrm{kg}$ & 73.42 & 93.64 & 77.98 & 103.47 & 104.95 & 88.13 & 541.59 \\
\hline
\end{tabular}




\begin{tabular}{|c|c|c|c|c|c|c|c|c|c|}
\hline \multirow[b]{2}{*}{$\frac{\dot{\Xi}}{\grave{E}}$} & \multirow[b]{2}{*}{$\begin{array}{c}\text { Name of } \\
\text { foods that are } \\
\text { purchased }\end{array}$} & \multirow[b]{2}{*}{ 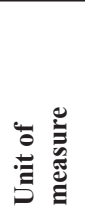 } & \multicolumn{7}{|c|}{ Annual consumption by ships } \\
\hline & & & 㐫 & 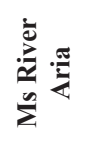 & 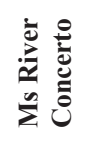 & 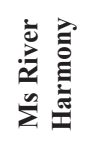 & 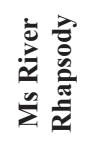 & 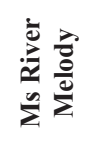 & Total \\
\hline 3 & $\begin{array}{l}\text { Sausage smoked } \\
\text { Rockworst }\end{array}$ & $\mathrm{kg}$ & 103.56 & 62.56 & 85.28 & 140.7 & 209.98 & 197.06 & 799.14 \\
\hline \multicolumn{10}{|c|}{ Boiled sausage - finely minced boiled sausage } \\
\hline 4 & $\begin{array}{l}\text { Sausage Bavarian } \\
\text { white }\end{array}$ & $\mathrm{kg}$ & 7 & 75.6 & 79.8 & 92.4 & 71.4 & 67.2 & 420 \\
\hline 5 & $\begin{array}{l}\text { Cold cuts turkey } \\
\text { assorted }\end{array}$ & $\mathrm{kg}$ & 103.77 & 257.43 & 115.93 & 82.67 & 50.51 & 156.14 & 766.45 \\
\hline 6 & Cold cuts assorted & $\mathrm{kg}$ & 128.28 & 50.26 & 200.17 & 204.11 & 155.47 & 255.63 & 993.92 \\
\hline 7 & Sausage Vienna & $\mathrm{kg}$ & 84 & 127 & 60 & 110 & 86 & 96 & 563 \\
\hline \multicolumn{10}{|c|}{ Boiled sausages - rough chopped boiled sausages } \\
\hline 8 & $\begin{array}{l}\text { Sausages } \\
\text { Bratwurst } \\
\text { Thuringer }\end{array}$ & $\mathrm{kg}$ & 140 & 140 & 152 & 184 & 152 & 216 & 984 \\
\hline 9 & $\begin{array}{l}\text { Sausage Breakfast } \\
(20-25 \mathrm{gr})\end{array}$ & $\begin{array}{l}\text { piece/ } \\
\mathrm{kg}\end{array}$ & 20,420 & 24,150 & 17,270 & 19,600 & 17,295 & 19,380 & $\begin{array}{c}118,115 \text { or } \\
2,362.3\end{array}$ \\
\hline \multicolumn{10}{|c|}{ Boiled sausage with chunks meat } \\
\hline 10 & $\begin{array}{l}\text { Ham cooked } \\
\text { breakfast }\end{array}$ & $\mathrm{kg}$ & 674.76 & 565.13 & 460.57 & 485.67 & 648.9 & 575.48 & $3,410.51$ \\
\hline \multicolumn{10}{|c|}{ Boiled sausage } \\
\hline 11 & Pate fine & $\mathrm{kg}$ & 81.04 & 43.86 & 40.8 & 48.16 & 45.88 & 39.02 & 298.76 \\
\hline 12 & Pate veal liver & $\mathrm{kg}$ & 37.17 & 46 & 38.55 & 42.34 & 55.22 & 61 & 280.28 \\
\hline 13 & $\begin{array}{l}\text { Pate veal liver } \\
\text { portions } \\
(20-25 \mathrm{gr})\end{array}$ & piece & 1140 & 1356 & 1300 & 1423 & 921 & 1160 & $\begin{array}{l}7,300 \\
\text { or } 146\end{array}$ \\
\hline 14 & Sausages blood & $\mathrm{kg}$ & 23.62 & 10.8 & 17.96 & 36.14 & 38.3 & 41.7 & 168.52 \\
\hline \multicolumn{10}{|c|}{ Smoked products } \\
\hline 15 & Ham black forest & $\mathrm{kg}$ & 106.74 & 91.94 & 53.58 & 17.24 & 38.78 & 101.43 & 409.71 \\
\hline 16 & Cobourger ham & $\mathrm{kg}$ & 26.96 & 69.28 & 65.24 & 151.8 & 170.96 & 38.84 & 523.08 \\
\hline 17 & $\begin{array}{l}\text { Cold cuts turkey } \\
\text { breast smoked }\end{array}$ & $\mathrm{kg}$ & 59.98 & 60.34 & 30.92 & 56.62 & 114.6 & 74.74 & 397.2 \\
\hline \multicolumn{10}{|c|}{ Products of minced meat } \\
\hline 18 & $\begin{array}{l}\text { Minced mixed } \\
\text { meat }\end{array}$ & $\mathrm{kg}$ & 858 & 665 & 592 & 486 & 552 & 535 & 3688 \\
\hline 19 & Beef Hamburger & $\mathrm{kg}$ & 90 & 167 & 137.2 & 169.68 & 169.5 & 187.36 & 920.74 \\
\hline \multicolumn{9}{|c|}{ Total } & $26,318.9$ \\
\hline
\end{tabular}

Source: Internal documentation of Grand Circle Corporation, 2013.

The data obtained about the total annual consumption of meat and meat products from the chosen sample in the company "Grand Circle Cruise Line" is represented in Graph 1. According to the data described above, it can be concluded that the consumption of poultry meat in the amount of $27 \mathrm{t}$ is the biggest, followed by other meat products in the amount of $26 \mathrm{t}$. 
Graph 1. - Consumption of meat products "Grand Circle Cruise Line" in 2013

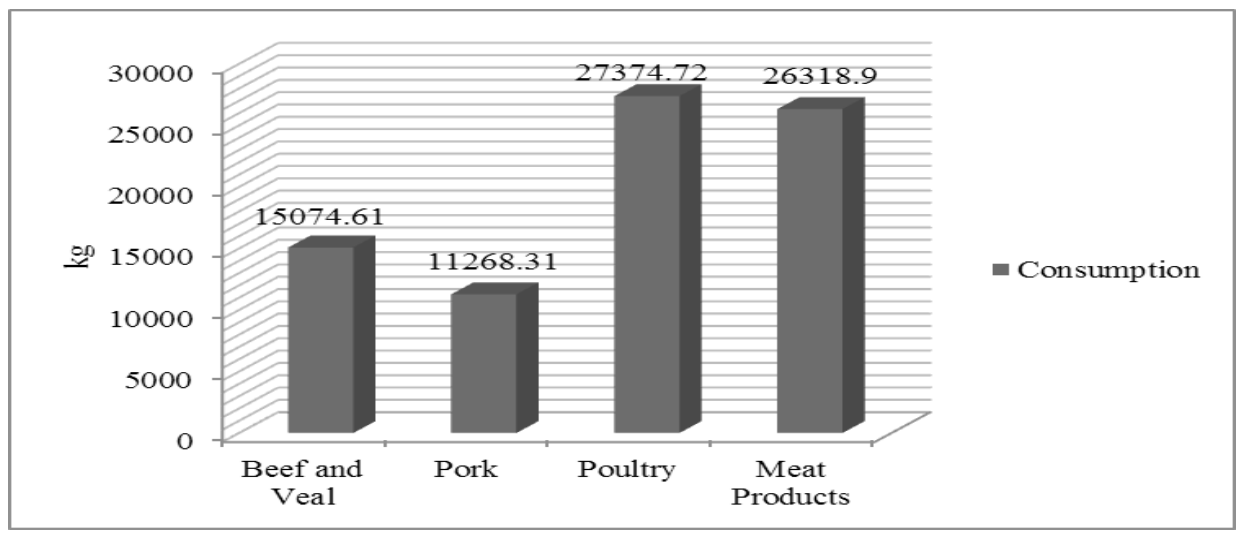

Source: raw data compiling

\section{Meat consumption on the Danube in Serbia}

Eight companies with 54 tourist ships sail on the Danube through the Republic of Serbia (Dragin et al., 2014). The ships have a relatively constant number of passengers. The results obtained in the studied sample indicate that the overall consumption of 54 ships would result in roughly 218 thousand tons of poultry and 120 thousand tons of veal and beef annually. The consumption of meat products is approximately 210 thousand tons and pork about 89 thousand tons annually. Since the number of ships sailing on the Danube is expected to increase every year and therefore it can be expected that the amount of meat consumption would increase accordingly.

\section{Meat industries in the Republic of Serbia and their possibilities}

Based on the data retrieved from the Government run Agency for company registration (http://www.apr.gov.rs/), the following meat-producing companies are categorized as medium (labeled 3) and large (labeled 4) companies (Regulations on the content and form of financial statements for companies, cooperatives, other legal entities and entrepreneurs, Official Gazette of the Republic of Serbia no. 114/06, 5/07 - correction, 119/08, 2/10, 101/12, 118/12 and no. 3/2014): Matijević d.o.o., Agroživ d.o.o. and Carnex a.d. Additionally, in order to provide a reliable cooperation, companies should to have financial liquidity, should be making profits, and hire more than 1000 employees, which all of the above named companies do. Therefore, these categories should be held as a criterion for further inclusion of companies into research and comparisons.

Assortment of fresh beef, veal, lamb and pork could be supplied to ships by: Matijević d.o.o. and Carnex a.d. provided that they meet international sanitary and other quality standards.

With application of international and European regulatory framework in terms of food safety and quality, and by adoption of a holistic and preventive approach to inspection and control in the meat industry (Rantsios, 2007) ships could be supplied with fresh poultry by 
the meat industries Agroziv d.o.o. and Matijević d.o.o.

Table 8 represents the possibilities and capacity in meat industries that may identify their interest in this segment.

Table 8. Portfolios of meat industries

\begin{tabular}{|l|l|}
\hline \multicolumn{2}{|c|}{ Portfolios of meat industries in the market of the Republic of Serbia } \\
\hline Matijević d.o.o. & $\begin{array}{l}\text { - contemporary lines of slaughter cattle capacity of } 1,500 \text { units/8 hours; } \\
\text { - contemporary line of slaughter poultry capacity of } 4500 \text { pieces/hour; } \\
\text { - line the deboning which by its capacity monitor the slaughter line; } \\
\text { - processing with a line filling of meat finished products up to } 120 \text { tons per day. }\end{array}$ \\
\hline Agroziv d.o.o. & $\begin{array}{l}\text { - slaughter capacity of } 24,000 \text { chicken per shift; } \\
\text { - line of slitting } 4,200 \text { chickens per hour; } \\
\text { - automatic packing machines - one hour to pack } 300 \mathrm{~kg} \text { of chicken meat. }\end{array}$ \\
\hline Carnex a.d. & $\begin{array}{l}\text { - } 100 \text { different kinds of product meat; } \\
\text { - annual production of } 18,000 \text { tons. }\end{array}$ \\
\hline
\end{tabular}

Source: www.matijevic.rs; www.agroziv.rs; www.carnex.rs

According to the analysis of the companies in table 8, the company Matijevic d.o.o. and Agroziv d.o.o. may identify their interest towards new segments of the market, i.e. export of poultry meat. All the meat industries mentioned above and others on the market of the Republic of Serbia could find their benefits and recognize their interests.

\section{Conclusion}

The number of ships sailing on the Danube is increased every year and it is expected that the meat consumption will increase too. At the time when the data was extracted (2013), the sampled company "Grand Circle Cruise Line" did not work with any supplier of meat or meat products from Serbia. Based on an analysis of the market and the meat industry offer in the Republic of Serbia, there are competent and competitive companies which can provide the supply of ships sailing through the country. Producers in the meat industry which met basic reliability criteria are: Matijević d.o.o. Agroživ d.o.o. and Carnex a.d. Meat industries on the market of the Republic of Serbia have met some standards of quality and are in the process of fulfilling all of them. It remains on the State to implement regulations that are in accordance with EU regulations in terms of food production, sanitation and quality and thus eliminate the biggest hurdle in exporting the agro-food products. This would also bring in more revenues in form of taxes for the State. However, until all of the regulations are in place, it is unlikely the cruisers will employ Serbian meat-producers. Each passing cruising season without the regulations in place costs the Republic of Serbia significant amount of money in a wasted potential. Once all of the regulation is in place, and Serbian meat-producers can make use of their producing potential, they will have to put together a carefully drafted and competitive pricing list in order to encourage potential buyers. The future researches should include repeated studies in different companies and compare the results. Additionally, the possibility to export other foodstuffs should be researched. 


\section{Literature}

1. Cruise Market Watch (2012): Cruise Market Watch Announces 2013 Cruise Trends Forecast, portal Cruise Market Watch (posted $26^{\text {th }}$ Nov 2012), available at: www. cruisemarketwatch.com/articles/cruise-market-watch-announces-2013-cruisetrends-forecast, retrieved 15.01.2014.

2. Dragin, S. A., Đurđev, S. B., Armenski, T., Jovanović, T., Pavić, D., Ivkov Džigurski, A., Kosić, K., Favro, S. (2014): Analysis of the labour force composition on cruisers: The Danube through Central and Southeast Europe, Journal of Transport Geography, no. 39, pp. 62-72, Elsevier Ltd., available at: www.academia.edu/7795157

3. Dragin, A. S., Jovičić, D., Bošković, D. (2010): Economic impact of cruise tourism along the Pan-European Corridor VII, Economic Research, vol. 23, no. 4, pp. 127 141, University of Pula, Department of Economics and Tourism Dr. Mijo Mirkovic, Pula, Croatia.

4. Đenadić, M. (2010): Healthy food as a factor of Serbian tourism competitiveness, Economics of Agriculture, vol. 57, no. 4, pp. 681-690, IAE Belgrade, Serbia.

5. Đorović, M., Stevanović, S., Lazić, V. (2009): Globalno tržište mesa, Ekonomika poljoprivrede, vol. 56, no. 3, pp. 343-358, IAE, Belgrade, Serbia.

6. Đorović, M., Stevanović, S., Lazić, V. (2010): Srbija na međunarodnom tržištu mesa, Ekonomika poljoprivrede, vol. 57, no. 1, pp. 91-110, IAE, Belgrade, Serbia.

7. Fernandez Gines, J.M., Fernandez Lopez, J., Sayas Barbera, E., Perez Alvarez, J.A. (2005): Meat Products as Functional Foods: A Review, Journal of Food Science, vol. 70, no. 2, pp. 37-43, Institute of food technologists, available at: www.ift.org/

8. Grunert, G. K. (2006): Future trends and consumer lifestyles with regard to meat consumption, Meat Science, vol. 74, pp. 149-160, Elsevier, Philadelphia, USA.

9. Hrabovski Tomić, E. (2010): Agri business and food processing industry in the function of tourism industry's development, Economics of Agriculture, vol. 57, no. 3, pp. 487497, IAE Belgrade, Serbia.

10. Internal documentation of Grand Circle Corporation (2013), Boston, Massachusetts, USA.

11. Kalenjuk, B., Tešanović, D., Škrinjar, M., Vuksanović, N. (2011): Food potentials of Vojvodina and tourism development, Researches review of the Department of Geography, Tourism and Hotel Management, Faculty of Sciences, vol. 40, pp. $180-$ 187, Department of Geography, Tourism and Hotel Management, Novi Sad, Serbia.

12.Katić, A., Muhi, B., Stanković, J., Kovačević, J. (2011): Nautički turizam kao faktor konkurentnosti turizma Vojvodine, Industrija, vol. 39, no. 2, pp. 237-261, Ekonomski institut, Beograd, Srbija. 
13.Market Watch (2013): What's behind the river-cruise boom, portal Market Watch (posted $1^{\text {st }}$ Feb 2013), available at: www.marketwatch.com/story/whats-behind-theriver-cruise-boom-2013-02-01, retrieved 15.01.2014.

14. Meler, M., Cerović, Z. (2003): Food marketing in the function of tourist product development, British Food Journal, vol. 105, no. 3, pp. 175-92, Emerald Group Publishing Limited, Bingley BD16 1WA, United Kingdom.

15. Mihić, S., Golusin, M., Mihajlović, M. (2011): Policy and promotion of sustainable inland waterway transport in Europe - Danube River Review Article, Renewable and Sustainable Energy Reviews, vol. 15, no. 4, May 2011, pp. 1801-1809, Elsevier Ltd, available at: http://www.sciencedirect.com/science/article/pii/S1364032110004028

16. Petrović, M. M., Petrović, M. P, Petrović, M., Aleksić, S., Ostojić Andrić, D., Pantelić, V., Novaković, Ž. (2011): Kako u Srbiji povećati proizvodnju junećeg, jagnjećeg $i$ svinjskog mesa namenjenog domaćim potrebama i izvozu, Biotechnology in Animal Husbandry, vol. 27, no. 3, pp. 293-303, Institut za stočarstvo, Belgrade, Serbia.

17. Popović, V., Sarić, R., Jovanović, M. (2012): Sustainability of agriculture in Danube basin area, Economics of Agriculture, vol. 59, no. 1, pp. 73-87, IEA, Belgrade.

18. Rantsios, A. T. (2007): Novi pristupi u inspekciji i kontroli bezbednosti $i$ kvaliteta proizvoda od mesa, Tehnologija mesa, vol. 48, no. 1-2, pp. 29-35, Institut za higijenu i tehnologiju mesa, Beograd, Srbija.

19. Regulations on the meat quality of livestock for slaughter, poultry and game, Official Gazette of the Republic of Serbia, no. 34/74, 26/75, 13/78 - other Regulations, 1/81 other Regulation and 2/85 - other Regulations.

20. Regulations on quality of slaughtered pork and categorization of pork meat, Official Gazette of the Republic of Serbia, no. 2/85, 12/85 and 24/86.

21. Regulations on the quality of minced meat, meat preparations and meat products, Official Gazette of the Republic of Serbia, no. 31/2012 and 43/2013 - other Regulation.

22. Regulations on the content and form of financial statements for companies, cooperatives, other legal entities and entrepreneurs, Official Gazette of the Republic of Serbia no. 114/06, 5/07 - correction, 119/08, 2/10, 101/12, 118/12 and no. 3/2014.

23. Saba, A., Di Natale, R. (1999): A study on the mediating role of intention in the impact of habit and attitude on meat consumption, Food Quality and Preference, vol. 10, pp. 69-77, Elsevier, Philadelphia, USA.

24. Statistical office of Republic of Serbia (SORS), (2012): Statistički godišnjak Republike Srbije za 2012 godinu, SORS Belgrade, Serbia, available at: http://pod2.stat.gov.rs/ ObjavljenePublikacije/G2012/pdf/G20122007.pdf 
25. Statistical office of Republic of Serbia (SORS), (2014): Statistički godišnjak Republike Srbije za 2014 godinu, SORS Belgrade, Serbia, available at: http://webrzs.stat.gov.rs/ WebSite/repository/documents/00/01/53/32/09-Poljoprivreda.pdf

26. Tešanović, D., Kalenjuk, B., Vuksanović, N. (2010a): Svečani obroci-značajan segment turističkog proizvoda na rečnim brodovima, Turističko poslovanje, no. 5, pp. 251-262, Visoka turistička škola strukovnih studija, Beograd, Srbija.

27. Tešanović, D., Kalenjuk, B., Vuksanović, N. (2010b): Menadžment i struktura gastronomske ponude na turističkim rečnim brodovima, Četvrti biletarni međunarodni kongres, Hotelplan 2009 - hotelijerstvo i turizam, Hotellink 13-14, pp. 749-758, Visoka hotelijerska škola, Beograd, Srbija.

28. Tešanović, D., Vuksanović, N., Kalenjuk, B., Vukić, M., Gagić, S. (2013): Danube tourist ship as an opportunity for export of agricultural and food products, Economics of Agriculture, vol. 60, no. 1, pp. 179-194, IAE, Belgrade, Serbia.

29. Vitez, M., Raičević, V. (2008): Saobraćaj unutrašnjim vodenim putevima - potencijal za razvoj Srbije, Pravo - teorija i praksa, vol. 25, no. 3-4, pp. 10-19, Univerzitet Privredna akademija, Novi Sad, Srbija.

30. Vlahović, B., Štrbac, M. (2006): Obeležja potrošnje pilećeg mesa u evropskim zemljama, Letopis naučnih radova, vol. 30, no. 1, pp. 175-183, Poljoprivredni fakultet, Novi Sad, Srbija.

31. Vlahović, B., Puškarić, A. (2006): Uporedna analiza potrošnje mesa u balkanskim zemljama, Savremena poljoprivreda, vol. 55, no. 1-2, pp. 21-27, Dnevik-Poljoprivrednik AD, Novi Sad, Srbija.

Web sites:

32. http://www.apr.gov.rs/

33. http://www.agroziv.rs/

34. http:/www.carnex.co.rs/

35. http:/www.matijevic.rs/ 


\title{
TURISTIČKI BRODOVI DUNAVA KAO ŠANSA ZA IZVOZ PROIZVODA OD MESA ${ }^{6}$
}

\author{
Dragan Tešanovičc7, Nikola Vuksanović ${ }^{8}$, Bojana Kalenjuk ${ }^{9}$, Milijanko Portic ${ }^{10}$
}

\section{Rezime}

Razvoj turizma pokreće rast drugih komplementarnih delatnosti. Nautički turizam, kao poseban selektivni oblik turizma, doživljava intenzivni razvoj, sa značajem za regije kroz koje, Dunav kao sastavni deo sistema Rajna - Majna - Dunav, protiče. Tokom krstarenja najveća potrošnja se ostvaruje na samom brodu, gde meso i proizvodi od mesa kao sastavni element svakog obroka prestavlja najskuplju komponentu hrane. Zadatak rada je da se izvrši analiza potrošnje mesa i proizvoda od mesa na šest turističkih brodova kompanije „Grand Circle Corporation “ $u$ 2013. godini, s ciljem da se ukaže na mogućnost snabdevanja mesom i prerađevinama iz proizvodnih izvora sa teritorije kojom brodovi prolaze. U radu će biti prikazani aktuelni snabdevači, kao i proizvođači iz Republike Srbije koji bi mogli snabdevati kompaniju „, Grand Circle Cruise Line“ $i$ druge turističke brodove na Dunavu. Takođe, istraživanje ukazuje da bi izvoz mesa i proizvoda od mesa za Republiku Srbiju, pod pretpostavkom da snabdeva većinu turističkih brodova, imao značajan efekat $u$ boljem pozicioniranju i povećanju konkurentnosti u sektoru poljoprivredne i prehrambene proizvodnje. Rezultati rada, posebno, ukazuju na mogućnost povećanja izvoza živinskog $i$ goveđeg mesa ukoliko bi se iskoristio potencijal tražnje svih osam kompanija koje sa 54 broda obavljaju turistička putovanja na Dunavu. Dobijeni podaci su sistematizovani, statistički obrađeni i tabelarno i graficki prikazani.

Ključne reči: turistički brodovi Dunava, meso i prerađevine od mesa, izvoz.

6 Rad je deo projekta pod brojem III 46009 i III 46005, finansirani od strane Ministarstva prosvete, nauke i tehnološkog razvoja Republike Srbije.

7 Dr Dragan Tešanović, redovni profesor, Prirodno-matematički fakultet, Departman za geografiju, turizam i hotelijertsvo, Trg Dositeja Obradovića 3, 21000 Novi Sad, Srbija, Telefon: +381 63541 436, E-mail: tesanovic.dragan@gmail.com

8 Nikola Vuksanović, M.Sc, asistent, Visoka škola strukovnih studija za menadžment i poslovne komunikacije, Mitropolita Stratimirovića 110, 21205 Sremski Karlovci, Srbija, Telefon: +381 63 1968 770, E-mail: vuksanovicnikola@yahoo.com;

9 Dr Bojana Kalenjuk, docent, Prirodno-matematički fakultet, Departman za geografiju, turizam i hotelijertsvo, Trg Dositeja Obradovića 3, 21000 Novi Sad, Srbija, Telefon: +381 6419902 35, E-mail: bojanakalenjuk@yahoo.com

10 Dr Milijanko Portić, vanredni profesor, Prirodno-matematički fakultet, Departman za geografiju, turizam i hotelijertsvo, Trg Dositeja Obradovića 3, 21000 Novi Sad, Srbija, Telefon: +381 63814 47 39, E-mail: porticprof@yahoo.com 